\title{
Analisis Teknis dan Ekonomis Dalam Penggunaan Bahan Bakar Biomassa Di Pusat Listrik Tenaga Uap Studi Kasus di PLTU PT. Suka Jaya Makmur
}

\author{
Akhdiyatul $^{1)}$, Erick Radwitya ${ }^{2)}$ dan Yudi Chandra ${ }^{3)}$ \\ ${ }^{1,2,3)}$ Program Studi Teknologi Listrik \\ Jurusan Teknik Elektro, Politeknik Negeri Ketapang. \\ email: ${ }^{1)}$ ariendhya@gmail.com, ${ }^{2)}$ erickradwitya@gmail.com, ${ }^{3)}$ chandra.yudi.2386@gmail.com
}

\begin{abstract}
Abstrak-Manajemen PLTU sedang mempertimbangkan untuk mengganti kayu dengan cangkang kelapa sawit sebagai bahan bakar boiler. Untuk mengambil keputusan apakah mereka akan mengganti bahan bakar, perlu dilakukan analisis secara teknis dan ekonomis dengan menghitung kebutuhan kalor boiler, konsumsi batubara, kayu, dan cangkang kelapa sawit yang diperlukan boiler, menghitung biaya sistem pembangkit, biaya energi per $\mathrm{kWh}$ dan penghematan biaya bahan bakar. Analisis teknis menunjukkan kebutuhan kalor boiler dengan kapasitas 32-33 ton/jam adalah 24.679.424 $\mathrm{kCal} / \mathrm{jam}$, dan jumlah cangkang lebih sedikit yang dibutuhkan daripada kayu dan batubara, yaitu 5,1 ton/jam atau 43.819,2 ton/tahun. Penggunaan cangkang sebagai bahan bakar menghasilkan faktor kapasitas pembangkit sebesar $68 \%$ dan faktor utilitas sebesar $\mathbf{7 3 \%}$. Analisis Ekonomi menunjukkan biaya sistem pembangkit (Cost of overall system) dengan bahan bakar batubara adalah $R p$. 27.515.442.381,-/tahun (\$ 2.028.414), dengan kayu Rp. 10.337.223.537,-/tahun(\$ 762.051), serta limbah padat kelapa sawit (cangkang)Rp. 13.191.510.166,/tahun (\$ 972.567). Namun demikian penggunaan kayu membutuhkan proses lebih lama untuk dapat digunakan sebagai bahan bakar, karena dalam kondisi lembab atau basah memerlukan waktu 5-6 hari untuk mengeringkannya baru dapat dibakar. Artinya adalah dari sisi efisiensi waktu kayu tidak praktis dapat langsung digunakan, akibatnya akan timbul biaya tambahan untuk mengatasinya.
\end{abstract}

Kata Kunci : Analisis Ekonomi, teknis, biaya sistem pembangkit

\section{Pendahuluan}

Penggunaan bahan bakar yang masih bersumber dari hasil alam bukan merupakan pilihan yang baik bagi perusahaan, karena bertentangan dengan program konservasi hutan dan lingkungan yang giat dilakukan oleh pemerintah pusat. Saat ini memang PT. Suka Jaya Makmur memegang Hak Penguasaan Hutan (HPH) terbesar di Kabupaten Ketapang, namun suatu waktu pemerintah pusat bisa menghentikan izin penguasaan hutan tersebut yang berakibat PLTU akan kehilangan salah satu sumber bahan bakarnya. Demikian halnya dengan penggunaan batubara, selain tingkat polusi yang tinggi dari gas hasil pembakaran, harga beli batubara relatif tinggi bahkan cenderung naik setiap tahun. Ini tentu berdampak pada pendapatan PLTU, dimana pendapatan bersih (net benefit) tetap setiap tahun Manuscript received 19-07-2018; revised 21-08-2018; accepted 23-09-2018 sedangkan pengeluaran untuk biaya bahan bakar cenderung bergerak naik dari tahun ke tahun.

Di kabupaten Ketapang terdapat 20 Pabrik Kelapa Sawit (PKS) yang sudah beroperasi, dengan potensi limbah 444,58 ton/hari [1]. Jika Harris dkk (2013), mengemukakan bahwa saat menggunakan bahan bakar cangkang PLTU 6 MW menghasilkan ouput rata - rata sebesar 4,8 MW/jam dan dalam $1 \mathrm{MW}$ output membutuhkan 1,02 ton cangkang dan pada saat menggunakan bahan bakar fiber PLTU $6 \mathrm{MW}$ menghasilkan output rata - rata 2,3 MW/jam, dalam $1 \mathrm{MW}$ output membutuhkan 1.83 ton fiber [2]. Dapat diasumsikan dari 444,58 ton/hari limbah padat dan $9 \%$ atau 90,9 tonnya adalah cangkang, maka energi listrik yang dihasilkan adalah sebesar 92,7 MW/jam. Dengan kata lain PLTU PT. Suka Jaya Makmur yang berkapasitas 7,5 MW hanya membutuhkan 7,6 ton/jam cangkang. Namun demikian dalam penelitian ini kebutuhan cangkang akan dihitung berdasarkan kebutuhan kalor yang diperlukan oleh boiler.

Pane dkk (2016) menyimpulkan bahwa Pabrik Kelapa Sawit (PKS) yang berkapasitas produksi 60 ton tbs/jam dapat membangkitkan daya listrik sekitar 3,61 MW dari limbah padat sedangkan limbah cair PKS menghasilkan biogas yang berpotensi membangkitkan daya listrik sekitar 1,45 MW. Biaya pembangkitan energi listrik berbahan bakar limbah padat PKS adalah sekitar Rp. 714,64 /kWh dan biaya pembangkitan energi listrik berbahan bakar biogas limbah cair PKS adalah sekitar Rp 1.106,04 /kWh [3]. Biaya pembangkitan energi listrik setiap PLTU relatif, tergantung dari biaya pembelian bahan bakar dan biaya tetap lainnya.

Bahan bakar alternatif yang bersumber dari limbah kelapa sawit dikenal dengan bahan bakar biomassa ataudisebut juga sebagai "fitomassa" dan seringkali diterjemahkan sebagai bioresource atau sumber daya yang diperoleh dari hayati. Menurut kamus bahasa Inggris Oxford, istilah "biomassa" pertama kali muncul dalam literatur pada tahun 1934 di dalam Journal of Marine Biology Association oleh ilmuan Rusia bernama Bogorov yang menggunakan biomassa sebagai tatanama. Terdapat beberapa teknologi untuk mengkonversi biomassa menjadi bahan bakar seperti yang dijelaskan pada gambar 1 . dibawah ini: 


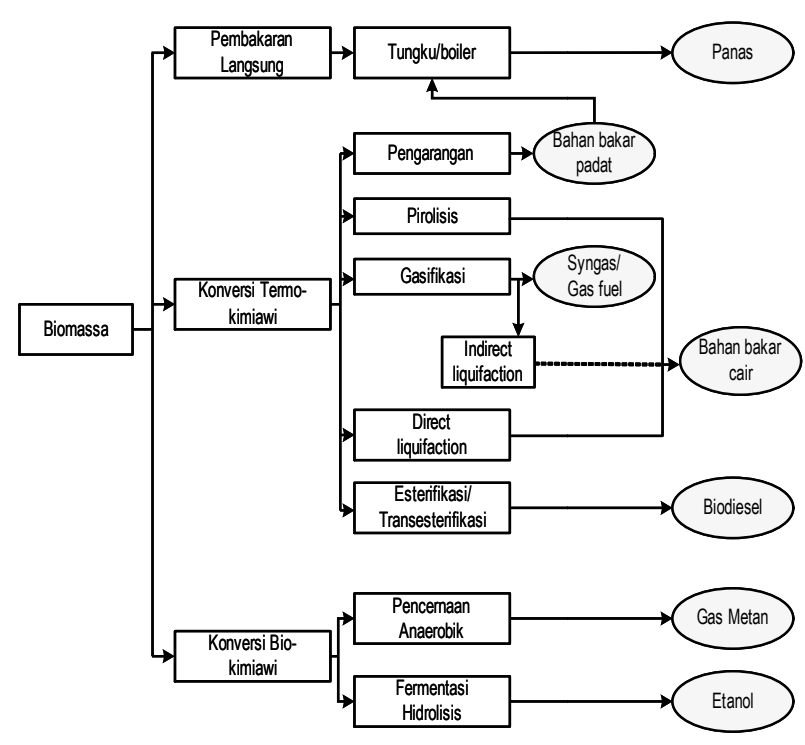

Gambar 1.Teknologi konversi biomassa[4]

Teknologi konversi biomassa limbah kelapa sawit adalah pengolahan sisa hasil tanaman kelapa sawit yang tidak termasuk dalam produk utama atau hasil ikutan dari pengolahan kelapa sawit menjadi bahan bakar. Gambar 2 . dibawah ini memperlihatkan produk utama dan produk sampingan yang dihasilkan dari pengolahan kelapa sawit [10].

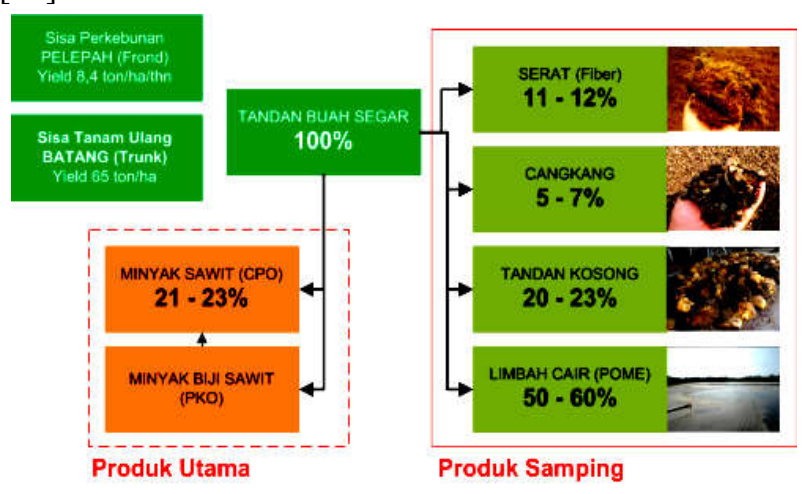

Gambar 2. Biomassa dari kelapa sawit[10]

Pembangkit listrik yang memanfaatkan limbah padat kelapa sawit sebagai bahan bakar salah satunya ialah PLTU. Secara umum prinsip kerja Pembangkit Listrik Tenaga Uap (PLTU) adalah mengkonversikan energi primer dari bahan bakar menjadi energi kalor/panas. PLTU biomassa sama dengan PLTU lainnya, yang berbeda adalah bahan bakar yang digunakan untuk memanaskan air sehingga menjadi uap. Jika disebagian PLTU menggunakan batubara, di PLTU biomassa menggunakan bahan bakar kayu, limbah padat kelapa sawit, dan limbah padat sisa hasil produksi lainnya sebagai bahan bakar untuk memanaskan air hingga berubah menjadi uap (steam).

Proses kerja atau mekanisme PLTU Biomassa PT. Suka Jaya Makmur, sebagai berikut:

a. Mempersiapkan transportasi bahan bakar

b. Proses Pembakaran pada boiler (Pulverization of Coal/CFB)

c. Monitoring dan control turbin d. Monitoring dan control pada generator dan sistem kelistrikan pembangkit

e. Waste and exhaust treatment

Dalam pengoperasian turbin uap, supaya menghasilkan uap bertekanan, maka yang menjadi fokus utama dijaga kestabilannya ialah pada unit boiler atau unit pengaturan bahan bakar yaitu: tekanan steam dijaga stabil pada $3,2-$ $3,7 \mathrm{MPa}$, temperatur steam stabil pada $420-445{ }^{\circ} \mathrm{C}$, tekanan vacuum stabil pada $\geq 0.086 \mathrm{MPa}$, dan level air pada drum dijaga pada rentang $-15 \sim 15 \mathrm{~mm}$ [9]. Parameter kendalian dapat dilihat pada gambar berikut:

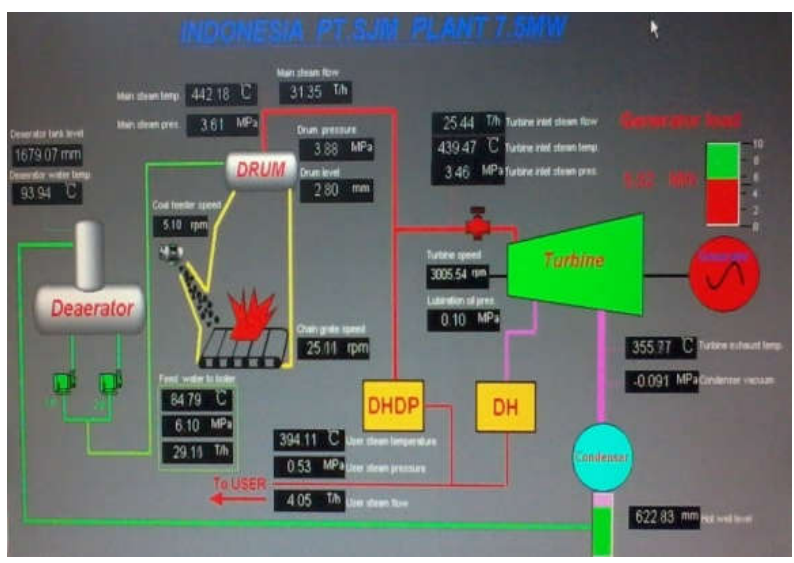

Gambar 3.Tampilan interface indikator yang di kendalikan operator[9]

Penelitian ini diharapkan memberikan penguatan secara teknis dan ekonomis sehingga limbah padat kelapa sawit dapat direkomendasikan sebagai bahan bakar alternatif untuk boiler oleh PLTU PT. Suka Jaya Makmur. Penggunaan limbah padat ini juga akan berpengaruh terhadap panas/kalor yang dihasilkan oleh boiler, oleh karena itu kebutuhan kalor boiler dihitung dengan pendekatan teoritis agar diketahui pula jumlah kebutuhan bahan bakar per jam. Biaya pembelian bahan bakar akan berpengaruh terhadap hasil perhitungan ekonomis, dimana akan dibandingkan biaya pembangkitan energi listrik per tahun dan biaya energi per tahun pada ketiga jenis bahan bakar yang digunakan oleh PLTU yakni batubara, kayu dan cangkang kelapa sawit.

\section{METODOLOGI PENELITIAN}

Penelitian dan pengambilan data dilakukan di Pusat Listrik Tenaga Uap (PLTU) milik PT. Suka Jaya Makmur dengan pertimbangan bahwa PLTU ini satu- satunya PLTU biomassa yang ada di Kabupaten Ketapang dan jarak tempuh tidak terlalu jauh sekitar 3 (tiga) $\mathrm{km}$ ke arah barat. Letak PLTU sendiri berada dalam area pabrik pengolahan plywoodPT. Suka Jaya Makmurdan tepat di tepi sungai Pawan untuk memudahkan dan meminimalkan jarak tempuh angkutan bahan bakar ke lokasi PLTU. Bahan bakar berupa potongan kayu yang dibentuk sedemikian rupa supaya mudah diangkut keatas tongkang (sejenis kapal besar tak bermesin yang biasanya digunakan untuk mengangkut barang) lalu ditumpuk digudang bahan bakar. Dalam melakukan penelitian ini, langkah-langkah yang dilakukan dibuat alur penelitian sebagai berikut: 


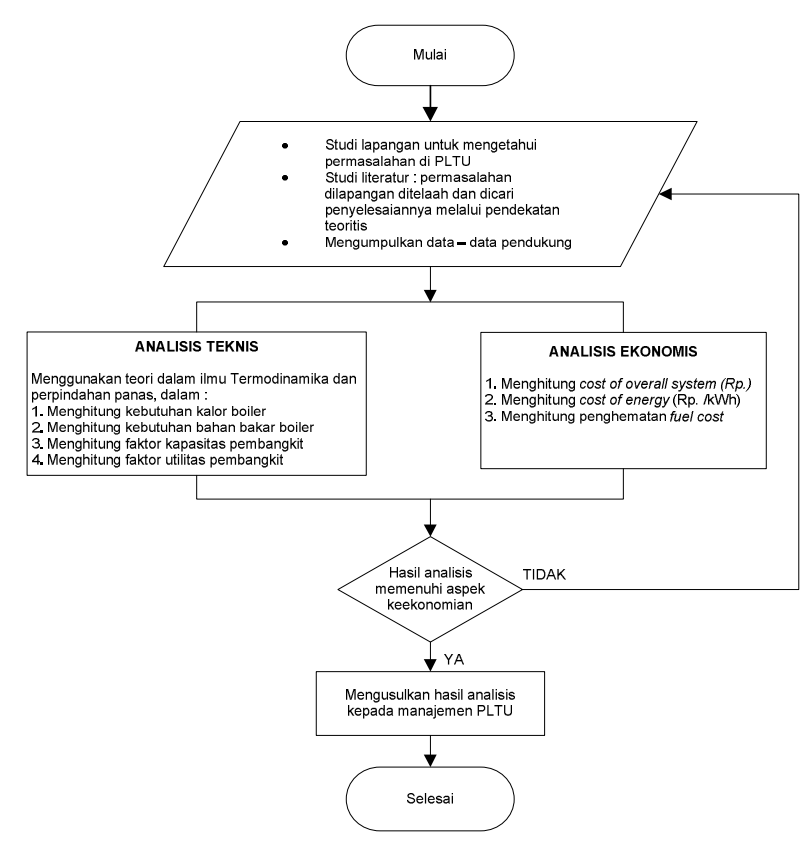

Gambar 4. Diagram alir penelitian

Gambar 5. dan 6. dibawah ini menunjukkan letak dan unit pembangkit milik PLTU PT. Suka Jaya Makmur.

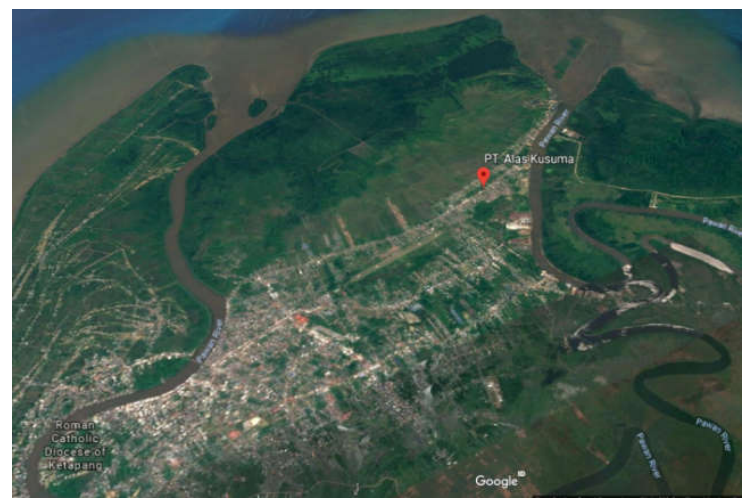

Gambar 5. Lokasi PLTU PT. Suka Jaya Makmur [Nopember 2017, Google Earth]

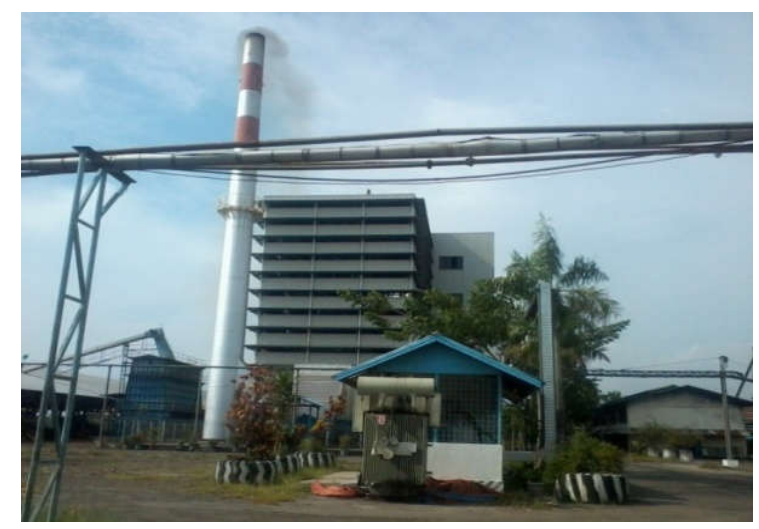

Gambar 6. Unit pembangkit PLTU[9]

Data yang digunakan dalam penelitian terdiri atas data primer dan data sekunder yang berasal dari lingkungan internal dan eksternal PLTU PT. Suka Jaya Makmur. Sesuai dengan diagram alir diatas, maka dilakukan tahapan penelitian dengan mengumpulkan berbagai informasi mulai dari data sistem pembangkit, spesifikasi boiler, turbin, dan generator, serta biaya pembelian bahan bakar, bahan kimia, bahan bakar minyak, biaya penunjang teknik, serta gaji karyawan.

Dalam proses mengubah air menjadi uap bertekanan (steam), boiler memerlukan sejumlah kalor yang dihasilkan dari pembakaran bahan bakar. Untuk menghitung kebutuhan bahan bakar, data awal yang di dapatkan adalah:

- Tekanan steam = 3,2-3,7 $\mathrm{MPa}$

- Temperatur steam $=420-445^{\circ} \mathrm{C}$

- Efisiensi $(\eta)$ boiler $=90 \%$

- Temp. air umpan boiler $=90-105{ }^{\circ} \mathrm{C}$

- Kapasitas boiler $=32-33$ ton/jam (dalam kondisi normal)

Kebutuhan kalor boiler dihitung:

$\mathrm{Q}_{\text {boiler }}=\frac{\mathrm{m} \cdot\left(\mathrm{h}_{\mathrm{v}}-\mathrm{h}_{\mathrm{i}}\right)}{\eta}$

dengan:

$\mathrm{Q}_{\text {boiler }}=$ Kebutuhan kalor boiler $(\mathrm{kJ} / \mathrm{jam})$

$m \quad=$ Kapasitas boiler $(\mathrm{kg} / \mathrm{jam})$

$\mathrm{h}_{\mathrm{v}} \quad=$ Entalpi uap panas lanjut

$\mathrm{h}_{\mathrm{i}} \quad=$ Entalpi air umpan masuk boiler

$\eta \quad=$ Efisiensi boiler (\%)

Dalam persamaan diatas, nilai entalpi uap panas lanjut dan nilai entalpi air umpan masuk boiler diketahui dari tabel temperatur uap air dan tabel uap panas lanjut. Kebutuhan bahan bakar boiler dihitung dengan persamaan:

$\mathrm{Q}_{\text {bahan bakar }}=\frac{\mathrm{Q}_{\text {boiler }}}{\text { nilai kalor bahan bakar }}$

Dimana:

$\mathrm{Q}_{\text {bahan bakar }}=$ Kebutuhan bahan bakar boiler ( $\left.\mathrm{kg} / \mathrm{jam}\right)$

Qboiler = Kebutuhan kalor boiler $(\mathrm{kJ} / \mathrm{jam})$

Nilai $Q_{b . b}=$ Nilai kalor bahan bakar $(\mathrm{kJ} / \mathrm{kg})$

Nilai kalor masing-masing jenis bahan bakar yang berbeda ini akan sangat mempengaruhi hasil perhitungannya [11]. Dari studi literatur, nilai kalor batubara yang digunakan oleh PLTU PT. Suka Jaya Makmur yaitu batubara dengan merk dagang ecocoal adalah $4.200 \mathrm{kCal} / \mathrm{kg}$. Nilai kalor kayu menurut Cahyono dkk (2008), dalam penelitian analisis nilai kalor dan kelayakan kayu sebagai bahan bakar menyimpulkan bahwa dalam penggunaannya, mengeringkankayu sampai kondisi kering tanur tidak ekonomis dari segi biaya. Untuknilai kalor optimum, kayu digunakan pada kondisi kering udara(kadar air 12\%) dengan nilai kalor berkisar 4.000 $\mathrm{kCal} / \mathrm{kg}$. Sedangkan Pricilia (2014), dalam penelitian tentang pemanfaatan cangkang dan fiber kelapa sawit menjadi energi listrik mendapatkan hasil pengujian sample dari laboratorium Institut Pertanian Bogor pada cangkang dengan nilai kalori $4.822 \mathrm{kCal} / \mathrm{kg}[1,6,4]$. Maka, dengan persamaan dibawah ini dihitung nilai kalor bahan bakar, yaitu:

$\mathrm{Q}_{\text {batubara }}=\frac{\mathrm{Q}_{\text {boiler }}}{\text { nilai kalor batubara }}$

$\mathrm{Q}_{\text {kayu }}=\frac{\mathrm{Q}_{\text {boiler }}}{\text { nilai kalor kayu }}$

$\mathrm{Q}_{\text {cangkang }}=\frac{\mathrm{Q}_{\text {boiler }}}{\text { nilai kalor cangkang }}$ 
Selanjutnya, kebutuhan bahan bakar dihitung dalam kapasitas penggunaannya per tahun. Kebutuhan masingmasing bahan bakar pertahun dihitung dengan:

Kebutuhan bahan bakar per tahun .

$=\mathrm{Q}_{\text {batubara }} x 24$ jam $x 358$ hari

Dalam satu tahun PLTU tidak beroperasi sepenuhnya 365 hari akan tetapi ada 7 (tujuh) hari untuk masa perawatan dan perbaikan sehingga waktu efektif beroperasinya PLTU adalah 358 hari. Penggunaan bahan bakar akan berdampak sepenuhnya pada keandalan sistem pembangkit yang direpresentasikan dalam faktor kapasitas dan faktor utilitas. Untuk menghitung faktor kapasitas dan faktor utilitas, data awal yang diperlukan adalah:

- Produksi listrik PLTU per tahun yaitu sebesar $37.760 .384 \mathrm{kWh}$

- Daya terpasang atau output daya normal yaitu 6.300 $\mathrm{kWh}$

- Daya mampu PLTU merupakan daya rata-rata tertinggi pembangkit yaitu beban pemakaian oleh PLN per tahun yaitu sebesar 2.094.547 $\mathrm{kWh}$ atau 2,09 MW, ditambah beban pemakaian aux. power turbine pabrik plywood PT. Suka Jaya Makmur yaitu 2,5 MW, jadi daya mampu PLTU adalah sebesar 4,59 MW.

Faktor kapasitas dihitung dengan:

Faktor kapasitas $=\frac{\text { Produksi satu tahun }}{\text { Daya terpasang } x 8760}$

Dan faktor utilitas dapat dihitung dengan:

Faktor utilitas $=\frac{\text { Daya mampu }}{\text { Daya terpasang }}$

Biaya-biaya yang harus dikeluarkan oleh PLTU PT. Suka Jaya Makmur merupakan biaya tetap yang terdiri dari biaya bahan bakar, gaji, biaya spare part/bbm/alat berat, biaya penunjang teknik dan biaya bahan kimia. Semua biaya-biaya tersebut lalu dikelompokkan dalam 2 (dua) jenis.

\section{1) Biaya Sistem Pembangkitan (Cost of Overall System)}

Biaya sistem pembangkitan (Cost of overall system) merupakan biaya tetap (fixed cost) yang harus dikeluarkan PLTU setiap tahun, dapat dihitung dengan persamaan:

$\mathrm{C}_{o s}=\mathrm{C}_{f}+\mathrm{S}+\mathrm{C}_{\mathrm{sp}}+\mathrm{C}_{\mathrm{t}}+\mathrm{C}_{\mathrm{k}}$

dengan:

$\mathrm{C}_{o s}=$ Cost of OverallSystem

$\mathrm{C}_{f}=$ Biaya bahan bakar

$\mathrm{S}=$ Gaji karyawan

$\mathrm{C}_{\mathrm{sp}}=$ Biaya spare part $/ \mathrm{bbm} /$ alat berat

$\mathrm{C}_{\mathrm{t}}=$ Biaya penunjang teknik

$\mathrm{C}_{\mathrm{k}}=$ Biaya bahan kimia

Biaya sistem pembangkitan akan dihitung dengan 3 (tiga) jenis bahan bakar yang berbeda, yaitu: batubara, kayu dan limbah padat kelapa sawit (cangkang) [8].

\section{2) Biaya Energi (Cost of Energy)}

Cost of Energy merupakan biaya yang dikeluarkan untuk menghasilkan energi listrik per $\mathrm{kWh}$, yang dihitung dengan [6]:

$$
\text { Cost of Energy }=\frac{\text { Cost of Overall system }}{\text { Produksi energi /tahun }}
$$

\section{Penghematan Biaya PLTU}

Penghematan biaya merupakan selisih antara biaya yang dikeluarkan PLTU saat ini yang menggunakan bahan bakar campuran $70 \%$ kayu dan $30 \%$ batubara dengan biaya yang dikeluarkan oleh PLTU menggunakan ketiga jenis bahan bakar yaitu batubara, kayu dan limbah padat kelapa sawit (cangkang). Penghematan biaya yang dihitung adalah penghematan biaya sistem pembangkit dan biaya energi. Dari data PLTU PT. Suka Jaya Makmur, biaya sistem pembangkit (Cost of Overall System) PLTU dari bahan bakar campuran batubara dan kayu adalah sebesar Rp. 24.836.873.520,- /tahun atau \$ 1.830.953 (\$1 = Rp. 13.595) [8]. Sedangkan Cost of Energy rata - rata per tahun dari bahan bakar yang digunakan PLTU saat ini yaitu campuran batubara dan kayu adalah senilai Rp. 751,-/kWh.

\section{HASIL DAN PEMBAHASAN}

Untuk mengetahui nilai entalpi uap panas lanjut dan entalpi air umpan masuk boiler dapat dilihat dalam tabel tekanan dan temperatur uap superheater. Dari tabel temperatur uap pada $\mathrm{T}=420{ }^{\circ} \mathrm{C}$ tidak diketahui nilainya, demikian halnya dengan $\mathrm{P}=3,5 \mathrm{MPa}$. Nilai ini diambil karena tekanan steam antara 3,2 - 3,7 $\mathrm{MPa}$, dantermasuk dalam tabel. Nilai entalpi pada $\mathrm{T}=420{ }^{\circ} \mathrm{C}$ yang tidak diketahui nilainya dicari menggunakan interpolasi linier, maka:

$$
\begin{aligned}
\mathrm{h}_{420} & =\frac{\mathrm{h}_{450}-\mathrm{h}_{400}}{\mathrm{~T}_{450}-\mathrm{T}_{400}} \cdot\left(\mathrm{T}_{420}-\mathrm{T}_{400}\right)+\mathrm{h}_{400} \\
\mathrm{~h}_{420} & =\frac{3338,1-3223,2}{450-400} \cdot(420-400)+3223,2 \\
\mathrm{~h}_{420} & =3269,16 \mathrm{~kJ} / \mathrm{kg}
\end{aligned}
$$

Untuk mengetahui nilai entalpi air umpan masuk boiler $\left(\mathrm{h}_{\mathrm{i}}\right)$ dilakukan hal yang sama, tetapi dapat dilihat langsung dari tabeltemperatur air umpan boiler diketahui $105{ }^{\circ} \mathrm{C}$. Nilai $h_{i}$ pada $T=105{ }^{\circ} \mathrm{C}$ dari tabel $=377,04 \mathrm{~kJ} / \mathrm{kg}$. Dengan demikian:

$$
\begin{aligned}
\mathrm{Q}_{\text {boiler }} & =\frac{32000 \cdot(3269,16-377,04)}{0,9} \\
& =102.830 .933 \mathrm{~kJ} / \mathrm{jam} \\
& =24.679 .424 \mathrm{kCal} / \mathrm{jam}
\end{aligned}
$$

Kebutuhan bahan bakar boiler dihitung dengan 3 (tiga) jenis bahan bakar yang berbeda, yaitu: batubara, kayu dan cangkang kelapa sawit. Nilai kalor masing-masing bahan bakar adalah:

$$
\begin{aligned}
& \text { Batubara } \quad=4.200 \mathrm{kCal} / \mathrm{kg} \\
& \text { Kayu } \quad=4.000 \mathrm{kCal} / \mathrm{kg} \\
& \text { Cangkang } \quad=4.822 \mathrm{kCal} / \mathrm{kg} \\
& \text { Maka,: } \\
& \mathrm{Q}_{\text {batubara }}=\frac{\mathrm{Q}_{\text {boiler }}}{\text { nilai kalor batubara }} \\
& =\frac{24.679 .424 \mathrm{kCal} / \mathrm{jam}}{4200 \mathrm{kCal} / \mathrm{kg}}
\end{aligned}
$$


$=5.876 \mathrm{~kg} / \mathrm{jam}$ atau 5,9 ton/jam

$$
\begin{aligned}
\mathrm{Q}_{\text {kayu }} & =\frac{\mathrm{Q}_{\text {boiler }}}{\text { nilai kalor kayu }} \\
& =\frac{24.679 .424 \mathrm{kCal} / \mathrm{jam}}{4000 \mathrm{kCal} / \mathrm{kg}} \\
& =6.170 \mathrm{~kg} / \mathrm{jam} \text { atau } 6,2 \text { ton } / \mathrm{jam} \\
\mathrm{Q}_{\text {cangkang }} & =\frac{\mathrm{Q}_{\text {boiler }}}{\text { nilai kalor cangkang }} \\
& =\frac{24.679 .424 \mathrm{kCal} / \mathrm{jam}}{4822 \mathrm{kCal} / \mathrm{kg}} \\
& =5.118 \mathrm{~kg} / \mathrm{jam} \text { atau } 5,1 \text { ton } / \mathrm{jam}
\end{aligned}
$$

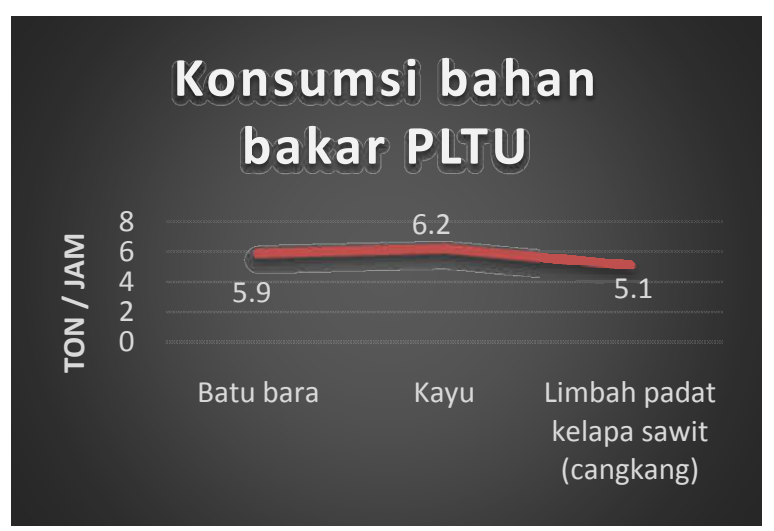

Gambar 7. Grafik konsumsi bahan bakar PLTU PT. SJM

Setelah diketahui kebutuhan bahan bakar untuk boiler dalam kapasitas ton/jam, maka kebutuhan bahan bakar per tahun dapat diketahui dengan:

Apabila menggunakan bahan bakar batubara, maka:

Kebutuhan batubara per tahun:

$=\mathrm{Q}_{\text {batubara }} x 24$ jam $x 358$ hari

$=5,9$ ton/jam $x 24$ jam $x 358$ hari

$=50.692,8$ ton $/$ tahun

Jika menggunakan bahan bakar kayu, maka kebutuhan kayu per tahun:

$=\mathrm{Q}_{\text {kayu }} x 24$ jam $x 358$ hari

$=6,2$ ton/jam $x 24$ jam $x 358$ hari

$=53.270,4$ ton/tahun

Jika menggunakan bahan bakar cangkang kelapa sawit, maka kebutuhan cangkang per tahun:

$=\mathrm{Q}_{\text {cangkang }} x 24$ jam $x 358$ hari

$=5,1$ ton/jam $x 24$ jam $x 358$ hari

$=43.819,2$ ton/tahun

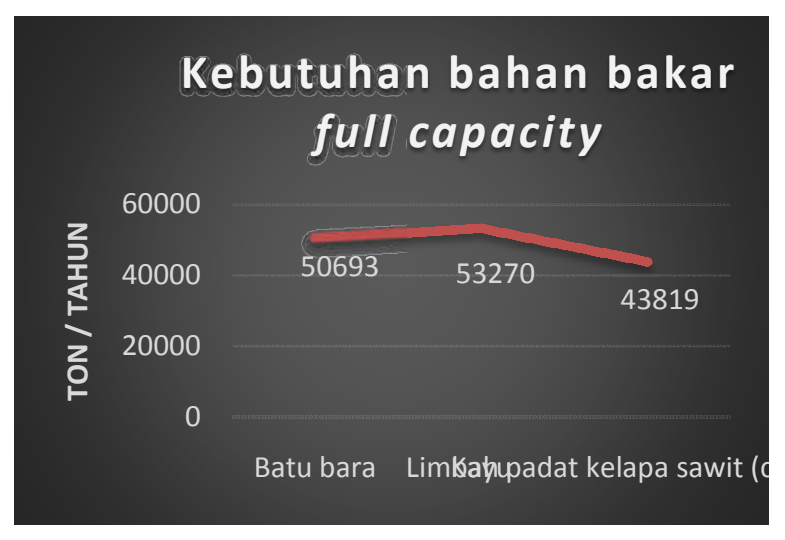

Gambar 8. Grafik kebutuhan bahan bakar PLTU full capacity per tahun

\section{Faktor kapasitas pembangkit}

Faktor kapasitas pembangkit dihitung dengan persamaan (7), yaitu,:

Faktor kapasitas $=\frac{\text { Produksi satu tahun }}{\text { Daya terpasang } x 8760}$

Faktor kapasitas tahunan adalah 8760 jam.

Produksi daya listrik per tahun diketahui dari data PLTU PT. Suka Jaya Makmur yaitu sebesar 37.760.384 kWh. Maka, faktor kapasitas pembangkit:

$$
\text { Faktor kapasitas }=\frac{37.760 .384 \mathrm{kWh}}{6300 \mathrm{kWh} \times 8760}=0,68 \text { atau } 68 \%
$$

\section{Faktor utilitas pembangkit}

Untuk menghitung faktor utilitas pembangkit, digunakan persamaan (8), yaitu:

Faktor utilitas $=\frac{\text { Daya mampu }}{\text { Daya terpasang }}$

Daya rata-rata tertinggi pembangkit merupakan beban pemakaian oleh PT. PLN per tahun yaitu sebesar 2.094.547 kWh atau 2,09 MW, ditambah beban pemakaian aux. power turbine pabrik PT. SJM yaitu 2,5 MW. Dan daya terpasang atau output daya normal diketahui dari data PLTU PT. Suka Jaya Makmur yaitu 6,3 MW. Maka, faktor utilitas pembangkit adalah:

$\begin{aligned} \text { Faktor utilitas } & =\frac{4.59 \mathrm{MW}}{6,3 \mathrm{MW}} \\ & =0,73 \text { atau } 73 \%\end{aligned}$

\section{Menghitung Cost of Overall System}

Cost of overall system merupakan biaya tetap (fixed cost) yang harus dikeluarkan PLTU setiap tahun. Biaya tetap ini terdiri dari biaya bahan bakar, gaji, biaya spare part/bbm/alat berat, biaya penunjang teknik dan biaya bahan kimia. Dapat dihitung dengan persamaan:

$\mathrm{C}_{o s} \quad=\mathrm{C}_{f}+\mathrm{S}+\mathrm{C}_{\mathrm{sp}}+\mathrm{C}_{\mathrm{t}}+\mathrm{C}_{\mathrm{k}}$

dengan:

$\mathrm{C}_{o s}=$ Cost of OverallSystem

$\mathrm{C}_{f}=$ Biaya bahan bakar

$\mathrm{S}=$ Gaji karyawan

$\mathrm{C}_{\mathrm{sp}}=$ Biaya spare part $/ \mathrm{bbm} /$ alat berat

$\mathrm{C}_{\mathrm{t}}=$ Biaya penunjang teknik

$\mathrm{C}_{\mathrm{k}}=$ Biaya bahan kimia 
Perbedaan jumlah kebutuhan bahan bakar ini juga akan mempengaruhi ongkos atau biaya bahan bakar, dimana batubara akan menghabiskan biaya bahan bakar sebesar Rp. 3.202.449,-/jam (\$ 236) atau Rp. 27.515.442.381,- /tahun (\$ 2.028.414). Kayu akan menghabiskan biaya Rp. 1.203.122,/jam (\$ 89) atau Rp. 10.337.223.537,- /tahun (\$ 762.051), dan limbah padat kelapa sawit (cangkang) akan menelan biaya Rp. 1.535.325,- /jam (\$ 113) atau Rp. 13.191.510.166,-/tahun (\$972.567).

Untuk gaji karyawan, data pengeluaran gaji yaitu sebesar Rp. 332.907.496,- /bulan (\$ 24.542) atau Rp. 3.994.889.952 /tahun (\$294.500).

Biaya spare part/bbm/alat berat merupakan biaya yang dikeluarkan oleh PLTU untuk komponen pendukung PLTU misalnya biaya pembelian spare part dan bbm alat berat, biaya spare part dan bbm dump truck, dan biaya spare part dan bahan bakar forklift. Untuk biaya ini adalah sebesar Rp. 67.795.281,- /bulan (\$ 4.998) atau Rp. 813.543.372,- /tahun (\$59.974).

Biaya penunjang teknik adalah biaya yang dikeluarkan untuk gaji, akomodasi dan transportasi bagi 4 (empat) orang teknisi WNA yang dikirim oleh perusahaan pembuat turbin dan boiler, yang besarnya ialah Rp. $66.184 .400,-$ /bulan $(\$$ 4.879) atau Rp. 794.212.800,- /tahun (\$ 58.549).

Biaya bahan kimia merupakan biaya yang dikeluarkan oleh PLTU untuk pembelian bahan kimia dalam proses pengolahan air sebelum masuk ke boiler untuk menghasilkan uap bertekanan, besarnya adalah Rp. 64.632.983,- /bulan (\$ 4.765) atau Rp. 775.595.796,- /tahun (\$57.176)

Dengan demikian, Cost of Overall System, dapat dihitung: Jika menggunakan batubara,

$\mathrm{C}_{o s}=\mathrm{C}_{f}+\mathrm{S}+\mathrm{C}_{s p}+\mathrm{C}_{t}+\mathrm{C}_{k}$

$=$ Rp. 27.515.442.381+Rp. 3.994.889.952 + Rp. 813.543.372 + Rp. 794.212.800+Rp. 775.595.796

$=$ Rp. 33.893.684.301,- /tahun $(\$ 2.498 .613)$

Jika menggunakan kayu,:

$\mathrm{C}_{o s} \quad=\mathrm{C}_{f}+\mathrm{S}+\mathrm{C}_{s p}+\mathrm{C}_{t}+\mathrm{C}_{k}$

$=$ Rp. 10.337.223.537+Rp. 3.994.889.952+Rp. 813.543.372 + Rp. 794.212.800 + Rp. 775.595 .796

$=$ Rp. 16.715.465.457,- /tahun ( $\$ 1.232 .250)$

Jika menggunakan limbah padat kelapa sawit (cangkang), $\mathrm{C}_{o s} \quad=\mathrm{C}_{f}+\mathrm{S}+\mathrm{C}_{s p}+\mathrm{C}_{t}+\mathrm{C}_{k}$

$=$ Rp. 13.191.510.166+Rp. 3.994.889.952+Rp. 813.543.372 + Rp. 794.212.800 + Rp. 775.595.796

$=$ Rp. 19.569.752.086,- / $/$ ahun $(\$ 1.442 .665)$

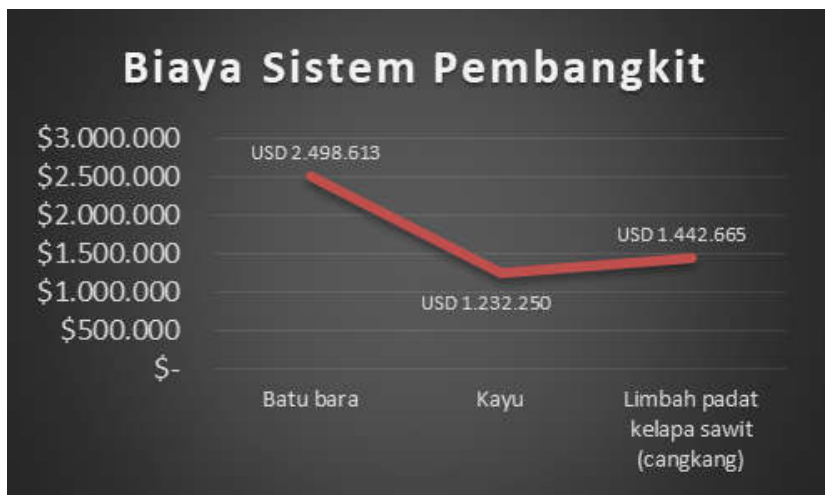

Gambar 9. Grafik biaya sistem pembangkit PLTU per tahun

\section{Menghitung Cost of Energy (CoE)}

Cost of Energy merupakan biaya yang dikeluarkan untuk menghasilkan energi listrik per kWh. Dapat dihitung dengan:

Cost of Energy $=\frac{\text { Cost of Overall system }}{\text { Produksi energi /tahun }}$

Jika menggunakan bahan bakar batubara, maka:

Cost of Energy $=\frac{\mathrm{Rp} \cdot 33.893 .684 .301}{37.760 .384 \mathrm{kWh}}$

$=$ Rp. $898,-/ \mathrm{kWh}$

Jika menggunakan bahan bakar kayu, maka:

$$
\begin{aligned}
\text { Cost of Energy } & =\frac{\text { Rp. 16.715.465.457 }}{37.760 .384 \mathrm{kWh}} \\
& =\text { Rp. } 443,-/ \mathrm{kWh}
\end{aligned}
$$

Jika menggunakan bahan bakar limbah padat kelapa sawit (cangkang), maka:

$$
\begin{aligned}
\text { Cost of Energy } & =\frac{\text { Rp. 19.569.752.086 }}{37.760 .384 \mathrm{kWh}} \\
& =\mathrm{Rp} .518,-/ \mathrm{kWh}
\end{aligned}
$$

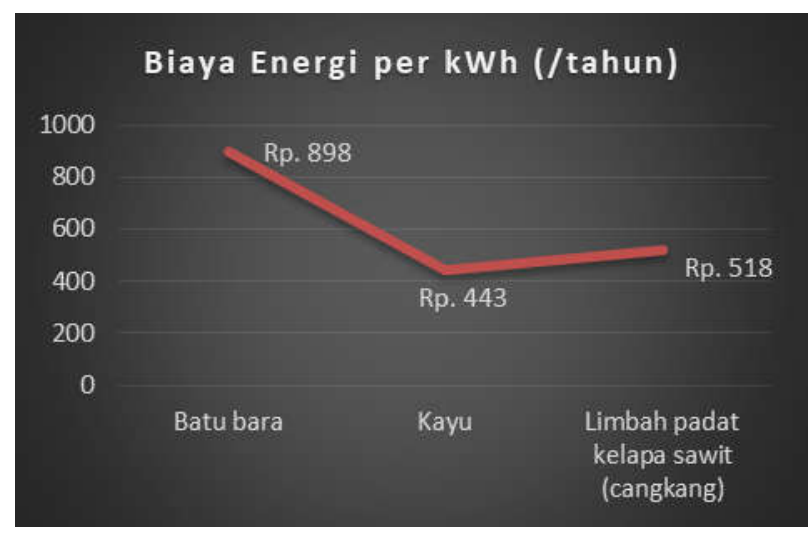

Gambar 10. Grafik biaya energi per kWh

\section{Menghitung penghematan biaya PLTU}

Cost of Overall System PLTU dari bahan bakar campuran batubara dan kayu adalah:

$$
\begin{aligned}
\mathrm{C}_{o s}= & \mathrm{C}_{f}+\mathrm{S}+\mathrm{C}_{s p}+\mathrm{C}_{t}+\mathrm{C}_{k} \\
= & \text { Rp. } 18.458 .631 .600+\text { Rp. 3.994.889.952 }+\mathrm{Rp} . \\
& 813.543 .372+\text { Rp. 794.212.800 }+\mathrm{Rp} . \\
& 775.595 .796 \\
= & \text { Rp. 24.836.873.520,- / tahun }(\$ 1.830 .953)
\end{aligned}
$$

Jika dibandingkan dengan penggunaan bahan bakar biomassa:

Maka, penggunaan kayu dapat menghemat:

$=$ Rp. 24.836.873.520 - Rp. 16.715.465.457

$=$ Rp. 8.121.408.063,- $/$ tahun $(\$ 598.703)$ atau $\pm 32,7 \%$

Penggunaan biomassa limbah padat kelapa sawit (cangkang) dapat menghemat:

=Rp. 24.836.873.520 - Rp. 19.569.752.086

$=$ Rp. 5.267.121.434,- /tahun (\$388.288) atau $\pm 21,2 \%$. 
Cost of Energy rata - rata per tahun dari bahan bakar yang digunakan PLTU saat ini yaitu campuran batubara dan kayu adalah senilai Rp. 751,-/kWh. Dengan demikian, penggunaan bahan bakar biomassa dapat menghemat Cost of Energy yang harus dikeluarkan oleh PLTU PT. Suka Jaya Makmur, sebesar:

Untuk bahan bakar kayu dapat menghemat

$=$ Rp. $751-$ Rp. $443=$ Rp. 308, $/ \mathrm{kWh}$ atau $\pm 41 \%$.

Untuk bahan bakar limbah padat kelapa sawit (cangkang) dapat menghemat:

$=$ Rp. $751-$ Rp. $518=$ Rp. $233,-/$ kWh atau $\pm 31 \%$.

\section{KESIMPULAN}

1. Telah didapatkan hasil analisis teknis yang menunjukkan bahwa kebutuhan kalor boiler PLTU PT. Suka Jaya Makmur dengan kapasitas normal 32-33 ton/jam adalah 24.679.424 kCal/jam, dan jumlah bahan bakar batubara yang diperlukan adalah 5,9 ton/jam atau 50.692,8 ton/tahun, dan bahan bakar kayu perlu 6,2 ton/jam atau 53.270,4 ton/tahun, sedangkan limbah padat kelapa sawit (cangkang) hanya diperlukan 5,1 ton/jam atau 43.819,2 ton/tahun. Limbah padat kelapa sawit (cangkang) lebih sedikit yang dibutuhkan daripada bahan bakar kayu dan batubara, yaitu 5,1 ton/jam atau 43.819,2 ton/tahun karena nilai kalori cangkang lebih tinggi dari batubara dan kayu.

2. Telah dilakukan perhitungan terhadap faktor kapasitas dan faktor utilitas pembangkit yang menggunakan bahan bakar biomassa dan hasilnya sistem pembangkit PLTU PT. Suka Jaya Makmur memiliki faktor kapasitas sebesar $68 \%$ dan faktor utilitas sebesar $73 \%$. Kondisi ini normal, karena sesuai referensi yang ada untuk nilai faktor kapasitas dan faktor utilitas sebuah pembangkit listrik tenaga uap berkisar antara $60-80 \%$.

3. Telah didapatkan hasil perhitungan biaya sistem pembangkit (Cost of overall system) yang menunjukkan bahwa dengan bahan bakar batubara menghabiskan biaya sebesar Rp. 3.202.449,- /jam (\$ 236) atau Rp. 27.515.442.381,- /tahun (\$2.028.414), dengan kayu akan menghabiskan biaya Rp. 1.203.122,- /jam (\$ 89) atau Rp. 10.337.223.537,-/tahun (\$ 762.051), serta limbah padat kelapa sawit atau cangkang akan menelan biaya Rp. 1.535.325,-/jam (\$ 113) atau Rp. 13.191.510.166,- /tahun (\$ 972.567).

4. Telah didapatkan hasil perhitungan biaya energi (Cost of Energy) per $\mathrm{kWh}$ yang dibutuhkan yaitu jika menggunakan bahan bakar batubara Rp. 898,-/kWh, kayu Rp. 443,-/kWh dan limbah padat kelapa sawit (cangkang) Rp. 518,-/kWh.

5. Telah dilakukan perhitungan untuk penghematan biaya sistem pembangkit dan biaya energi, hasilnya adalah kayu dapat menghemat Rp. 8.121.408.063,-/tahun (\$ $598.703)$ atau $\pm 32,7 \%$ dan limbah padat kelapa sawit atau cangkang dapat menghemat Rp. 5.267.121.434,/tahun (\$ 388.288) atau $\pm 21,2 \%$. Penghematan biaya energi (Cost of Energy) yang dikeluarkan oleh PLTU PT. Suka Jaya Makmur apabila menggunakan bahan bakar kayu dapat menghemat Rp. 308,-/kWh atau \pm $41 \%$ dan bahan bakar limbah padat kelapa sawit atau cangkang dapat menghemat Rp. 233,-/kWh atau $\pm 31 \%$. Penggunaan batubara tidak menghemat biaya sistem pembangkit dan biaya energi karena biaya yang dikeluarkan lebih besar dari biaya sistem pembangkit dan biaya energi saat ini.

\section{UCAPAN TERIMA KASIH}

Terima kasih kami sampaikan kepada managemen PLTU PT. Suka Jaya Makmur yang telah memberikan kesempatan bekerjasama dalam penelitian ini. Direktur dan rekan kerja program studi Teknologi Listrik Politeknik Negeri Ketapang, para dosen, staf.

\section{DAFTAR PUSTAKA}

[1] Badan Pusat Statistik Kabupaten Ketapang, "Ketapang Dalam Angka 2017”, ISSN 0215 - 4390, 2017.

[2] Harris, dkk, "Studi Pemanfaatan Limbah Padat dari Perkebunan Kelapa Sawit pada PLTU 6 MW di Bangka Belitung", Jurnal Teknik POMITS Vol. 2, No.1, ISSN : 23373539, Agustus 2013.

[3] Pane, N. E. Perkasa dan Kasim, S. Tarmizi, "Studi Potensi Energi Baru Terbarukan Untuk Mengatasi Defisit Pasokan Tenaga Listrik di Daerah Sumatera Utara", Jurnal Singuda Ensikom vol. 14 no. 38, , h. 1-6, Dep. Teknik Elektro Fak. Teknik Universitas Sumatera Utara, Januari 2016.

[4] Pricilia, SuciA., "Analisis Ekonomi Pemanfaatan Fiber dan Cangkang Kelapa Sawit Menjadi Energi Listrik (Studi Kasus : PT. Bahana Karya Semesta, Kab. Sarolangun, Jambi)", Skripsi Fakultas Ekonomi Dan Manajemen Institut Pertanian Bogor, Juni 2014.

[5] Cahyono, T.D dkk,"Analisis Nilai Kalor Dan Kelayakan Ekonomis Kayu Sebagai Bahan Bakar Substitusi Batubara di Pabrik Semen" Jurnal Forum Pascasarjana Vol. 31 No. 2 April 2008:105-116, Sekolah Pascasarjana IPB, April 2008.

[6] www.minerba.esdm.go.id, Harga Batubara Acuan Oktober 2016, Nopember 2016.

[7] www.bi.go.id / id/ moneter/ informasi-kurs / transaksibi / Default.aspx

[8] D. Marsudi., Pembangkitan Energi Listrik, Erlangga, Jakarta. 2005.

[9] PLTU PT. Suka Jaya Makmur, "Buku Panduan Pengoperasian dan Pemeliharaan Turbin Uap", Qingdao Jieneng Steam Turbine group co.ltd, Agustus 2010.

[10] S. Yokayama, Asian Biomass Handbook, Japan Institute of Energy, Nopember 2008.

[11] Aleksander Franky, Jamhir Islami., “ Analisis Tekno Ekonomi Energi Micro Wind Turbine Di Kawasan Perbatasan, Desa Temajuk Kecamatan Paloh Kabupaten Sambas", Jurnal ELKHA Vol.7 No.1, Maret 2015

[12] Toashin, A. "Buku Ajar Mesin Konversi Energi", Jurusan Teknik Mesin Politeknik Negeri Pontianak, 2006. 